\title{
ESSENTIAL ALIGNMENT: CORPORATE SOCIAL RESPONSIBILITY AND SOCIAL IMPACT ASSESSMENT FOR SUSTAINABLE DEVELOPMENT-AN EMPIRICAL STUDY
}

\author{
Dr. E. Manohar \\ Asst. Professor \& Principal \\ University College of Commerce and Business Management \\ Department of Business Management \\ Satavahana University, Telangana State, India. \\ Email: enugala.manohar@gmail.com
}

\begin{abstract}
ABTRACT
The impacts of Corporate Social Responsibility activities takes place in different forms. There is now a growing concern over the fate of the displaced people due to expansion of the companies. This has given rise to the need to understand beforehand the implications of adverse project impacts so that mitigation plans could be put in place in advance. The tremendous changes in the last decade of the twentieth century, the companies have witnessed a shift in focus from charity and traditional philanthropy toward more direct involvement of organisations in development of the needy and poorest of the society. In India, there is a growing need for alignment of Social Impact Assessment with Corporate Social Responsibility as the organisations cannot succeed in isolation but social progress is necessary for sustainable growth in the competitive world. The alignment of Social Impact Assessment (SIA) and Corporate Social Responsibility (CSR) programmes of companies need to focus on community initiatives at the local level which leads to sustainable development of the community and brings good image to the company. The present paper focuses on the essential alignment of Social Impact Assessment and Corporate Social Responsibility by the case studies of two public sector undertakings at Karimnagar region in Telangana State, India.
\end{abstract}

Key word: Social Impact Assessment (SIA), Corporate Social Responsibility (CSR), Alignment of Strategies and Sustainable Development

Cite this Article: Dr. E. Manohar, Essential Alignment: Corporate Social Responsibility and Social Impact Assessment for Sustainable Development - An Empirical Study, Journal of Management, 6 (3), 2019, pp. 186-191.

$\mathrm{http}: / / \mathrm{www}$. iaeme.com/JOM/issues.asp?JType=JOM\&VType=6\&IType=3 


\section{INTRODUCTION}

The companies in India have changed their style of functioning in the field of corporate social responsibility and industrial welfare has been put to practice since decades. The concept of CSR has been regarded as detrimental to a company's profitability, to being considered as somehow benefiting the company as a whole, at least in the long run. The companies have 'remodelled' themselves as good corporate by implementing CSR projects based on the local need. There is some risk in designing the CSR activities as the corporate policies are to be aligned with the local needs as they differ from place to place and region to the region. Before implementing the CSR activities, focus on Need Assessment Survey (NAS) and after implementation, Social Impact Assessment (SIA) is to be made.

\section{NEED FOR THE PRESENT STUDY}

Social impact assessment would help to determine the extent to which the community has been benefitted from the CSR - CD activities implemented in the areas like education, health and improving the economic status of the communities, thereby providing an understanding of the effectiveness of the existing programmes / activities. It would therefore propose the changes that need to be undertaken thereafter. The present study is done by taking into considerations social impact assessment and corporate social responsibility for sustainable development in the public sector undertakings existing in Karimnagar region of Telangana State, India.

\section{OBJECTIVES OF THE STUDY}

- To identify the issues involved target area of the firms establishment and expansion

- To prepare a comprehensive model for configuring Social Impact Assessment and Corporate Social Responsibility for sustainable development

- To determine the impact of the CSR-CD activity on the social / cultural / economic conditions of the people in communities

- To assess the changes in the quality of life among village communities through project interventions

\section{METHODOLOGY OF THE STUDY}

\subsection{Survey Method}

A survey is one of the best known and most popular methods of assessing a community's strengths and weaknesses. Surveys can be simple, targeting only a small group of community stakeholders, or complex, sampling large segments of a population. An effective community survey can reveal a wealth of useful and easily quantifiable information and is a good option for many projects. Careful planning is one of the most important aspects of a successful survey. The design of most surveys begins with a statement of purpose, or why the survey is being conducted. This has helped our research team to determine what types of questions to ask, how the survey should be administered, and who should be asked to take it. In general, it's best to keep a survey short, with easy-to-understand questions.

\subsection{Primary and Secondary Data}

The Survey method has been adopted to collect the data from the respondents like people in the village who are affected with the company's establishment and expansion for utilising the natural resources like coal, limestone and water. The other group of respondents are the employees involved in implementation of corporate social responsibility activities. 


\subsection{What is Social Impact Assessment ?}

Social Impact Assessment includes the processes of analysing, monitoring and managing the intended and unintended social consequences, both positive and negative, of planned interventions (policies, programs, plans, projects) and any social change processes invoked by those interventions.

Social Impact Assessment alerts the planners as to the likely benefits and costs of a proposed project, which may be social and/or economic. The knowledge of these likely impacts in advance can help decision-makers in deciding whether the project should proceed, or proceed with some changes, or dropped completely. The most useful outcome of a SIA is to develop mitigation plans to overcome the potential negative impacts on individuals and communities. The term social impact is used for the impact of a corporation on society on the economic, environmental and social dimension. Whereas environmental accounting methods have been embraced by academic analysis and a wide range of corporations (Burritt and Saka 2006, Schaltegger 2002), the landscape of social impact methods has yet to be categorized. The purpose that the categorization performed in this paper serves is twofold. Firstly, it allows for the analysis of status quo of the social impact methods for corporate social responsibility (CSR). Secondly, it aids the CSR manager in the navigation through the wide range of existing tools. Analogous to financial accounting methods, environmental and social accounting methods aim to measure the impact of corporate activities on society. Such social and environmental impacts are often not expressed by the market, do not have a market value and are therefore often ignored by corporations (Elkington 1999, Schaltegger and Burritt 2000, Lamberton 2005). However, accounting methods provide crucial information for managerial decision-making (accounting for decision-making) and for internal and external reporting (accounting for control) (Zimmerman 2009).

\subsection{Social Impact Assessment Process in India}

Social Impact Assessment helps to make project responsive to social development concerns. Development initiatives informed by social assessment alleviate poverty, enhance inclusion and building ownership while minimizing the compensation for adverse social impacts on the vulnerable and the poor.

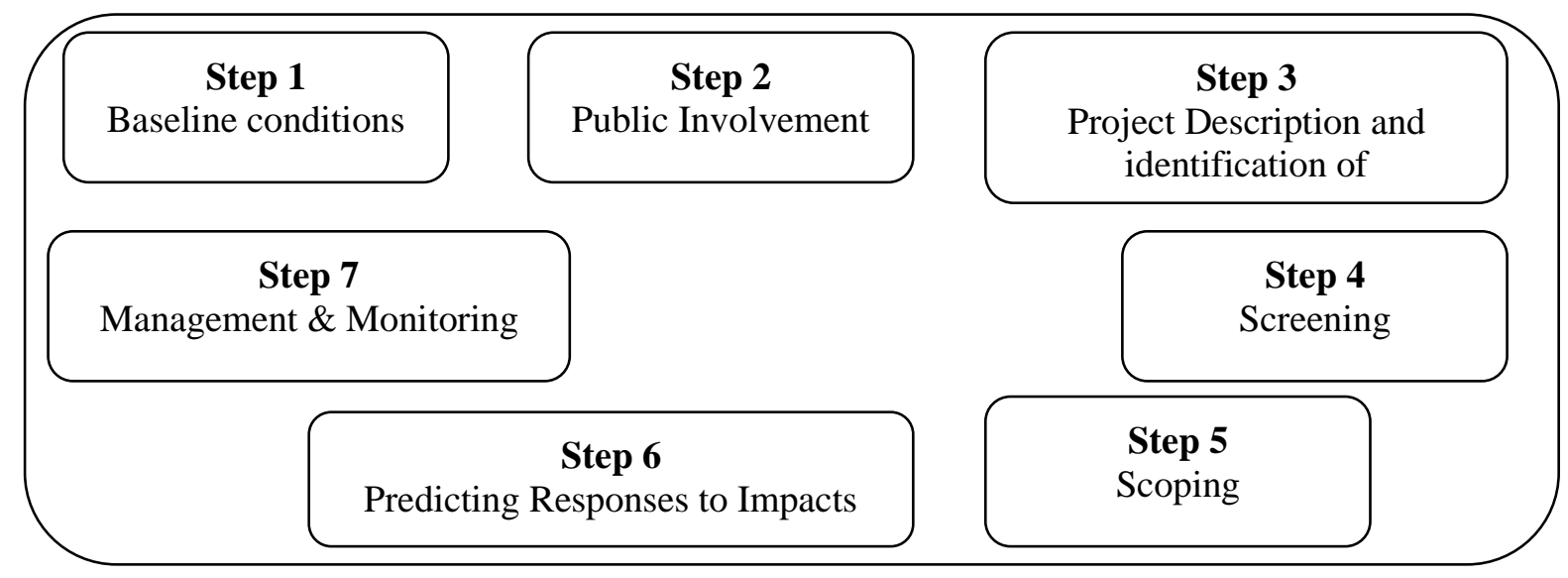

Figure 1 Social Impact Assessment Process

The Social Impact Assessment would begin with baseline conditions identification of the target area of the companies by involving the local people for evolving a suitable policy. The alternatives are to be identified without affecting people and their lives. If it becomes necessary, the alternatives are to be screened and scoping is to be done to minimize the risk. The companies 
have to predict the responses of impacts and help the people by providing suitable alternatives. Finally the relevant and acceptable policies have to implemented and monitored continuously by convincing the target area people.

\subsection{What is Corporate Social Responsibility?}

Corporate social responsibility is a concept that has become quite familiar in the world-ofbusiness today. The present-day conception of corporate social responsibility (CSR) implies that companies voluntarily integrate social and environmental concerns in their operations and interaction with stakeholders. CSR involves applying the concept of sustainable development to the corporate world. Companies that respect and listen to their stakeholders must naturally be concerned by their growth and profitability, but they must also be aware of the economic, environmental, social and societal impacts of their activities. Today, CSR in India has gone beyond merely 'charity and donations' and is approached in a more organized fashion. It has become an integral part of the corporate strategy (Das Gupta 2010). Now a day's companies have become more transparent in their balance sheet. They are incorporating their corporate social responsibility initiative in their annual report. Companies have CSR teams that devise specific policies, strategies and goals for their CSR programs and set aside budgets to support them. Companies in India have quite been proactive in taking up CSR initiatives and integrating them in their business processes. The CSR has three basic principles:

- Accountability

- Transparency

- Sustainability

The relevance of CSR within an organization CSR is not only relevant because of a changing policy environment but also because of its ability to meet business objectives. Undertaking CSR initiatives and being socially the following:

- Strengthening relationships with stakeholders

- Enabling continuous improvement and encouraging innovation

- Attracting the best industry talent as a socially responsible company

- Additional motivation to employees

- Risk mitigation because of an effective corporate governance framework

- Enhanced ability to manage stakeholder expectations engaged in CSR are revisiting their strategies and expanding inclusivity in growth.

There are about 100 companies which are focusing more on Corporate Social Responsibility activities and among them top ten companies are listed below:

Table 1 Corporate Social Responsibility activities

\begin{tabular}{|c|l|c|}
\hline SI No. & \multicolumn{1}{|c|}{ Name of the Company } & Rank \\
\hline 1. & Tata Steel & 2 \\
\hline 2. & Tata Power Company Ltd & 3 \\
\hline 3. & Ultra Tech Cement Ltd & 4 \\
\hline 4. & Mahindra \& Mahindra & 5 \\
\hline 5. & Tata Motors Ltd.5 & 6 \\
\hline 6. & Tata Chemicals Ltd. & 7 \\
\hline 7. & ITC Ltd & 8 \\
\hline 8. & Shree Cements Ltd & 9 \\
\hline 9. & Bharat Petroleum Corporation Ltd & 10 \\
\hline 10. & Larsen \& Toubro Ltd & 2016 \\
\hline
\end{tabular}

https://www.futurescape.in/india-top-companies-for-sustainability-and-csr-2016 


\subsection{Identified Issues}

The survey has been made in the target area of the study in Karimnagar region of Telangana State, India by administering the questionnaire to the respondents with the sample of 300 in 6 villages and identified the impacting issues due to establishment and expansion of the companies. The issues are

- Basic issue of community cohesion

- Disintegration of social support activities in the villages

- Disruption of women's economic activities are collapsed

- Loss of religious sites and other cultural property

- Loss of agricultural lands, tress, wells and houses

- Loss of access to common property resources

- Loss of small business units and employment opportunities

- School buildings, hospitals, roads, street lights and health standards

\section{CHALLENGES TO CSR INITIATIVES}

\subsection{A gap in involvement of community in CSR activities}

In implementation of CSR activities, communities who are the intended beneficiaries of a CSR program show less interest which will affect their participation and contribution. And very little efforts are being made to spread CSR within the local communities and in still confidence in the people. The situation is further aggravated by inadequate communication between the organization and the community at the grassroots level.

\subsection{Build the capacities of people involved in CSR activities}

The employees involved in the CSR activities are not adequately trained and equipped to operate efficiently and effectively as there is serious dearth of trained and efficient organizations that can seriously compromises efforts to scale CSR initiatives and consequently limits the scope and outcome of a company's CSR initiatives.

\subsection{Issues of information sharing with communities}

The perceived lack of transparency has a negative impact on the process of trust building between companies and local communities, which is key to the success of any CSR initiative. The gap has been found between the companies and communities in sharing the information related to CSR activities.

\subsection{Lack of confidence and consensus}

There is a lack of consensus amongst local agencies regarding CSR project needs and priorities. This results in lack of consensus often results in duplication of activities by corporate houses in their areas of their intervention. The consequence results in unhealthy competitiveness spirit among local implementing agencies, which goes against the necessity to have rather than building collaborative approaches on important issues. This factor limits organization's abilities to undertake impact assessment of their initiatives from time to time. 


\section{Strategies for Aligning Social Impact Assessment and Corporate Social Responsibility Activities}

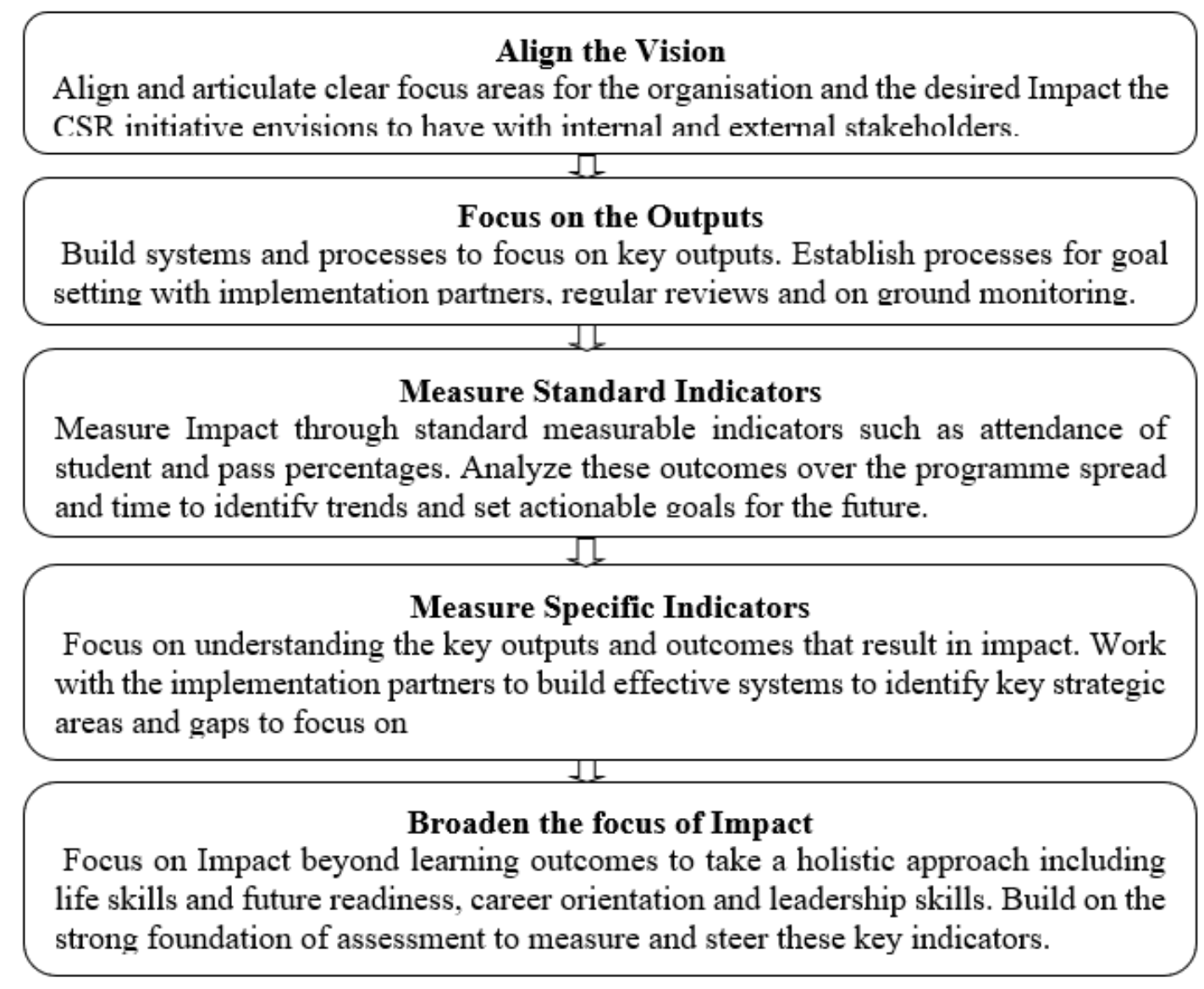

Figure 2 Strategies for Aligning Social Impact Assessment

\section{CONCLUSION}

In sustainable development Corporate Social Responsibility and Social Impact Assessment would share foundation value. SIA is a tool tools used to identify the environmental, social and economic impacts of a project prior to decision-making in Indian context. When proper alignment of Corporate Social Responsibility and Social Impact Assessment is done, it leads to effective implementation of CSR projects in the target areas of the organisations more specifically; it would help the society to the larger extent by using the strategies of alignment.

\section{REFERENCES}

[1] Burritt RL and Saka C 2006, 'Environmental management accounting applications and ecoefficiency: Case studies from Japan', Journal of Cleaner Production, vol. 14, pp. 1262-1275.

[2] Das Gupta A (ed) (2010) Ethics, business and society (Sage, Singapore).

[3] Elkington J 1999, Cannibal with forks, the triple bottom line of 21st century business, Capstone, Oxford.

[4] Lamberton G 2005, Sustainability accounting--a brief history and conceptual framework, Accounting Forum, vol. 29, no.1, pp. 7-26.

[5] Schaltegger S and Burritt R 2000, Contemporary environmental accounting, issues, concepts and practice, Greenleaf Publishing, Sheffield.

[6] Zimmerman JL 2009, Accounting For Decision Making And Control, McGraw-Hill Education, New York. 